\title{
Chapter 4 \\ Other Side, Other Woman: \\ Lady Oracle
}

Like The Golden Notebook, Margaret Atwood's 1976 novel Lady Oracle is acutely aware of its own status within the problematic category of "women's writing." Unlike The Golden Notebook, however, Lady Oracle plays at being representative of the most popular, and the most popularly maligned, tendencies in this category, in that its narrative mode from the outset is "confessional" in overtly massmarket terms. From the beginning, Joan Foster operates with the avowed intention of telling her side of the story, a story that by implication has already been told-badly, erroneously, misleadingly. Her aim, in the best "confessional" tradition, is to tell it "as she sees it," as it appears "through her own eyes." But in telling the other side, she is immediately implicated in describing her own situation under the gaze of others: of the people who variously constitute her according to their own requirements. The other side of her story is the story of her construction by others, who estrange her inasmuch as they occupy their own side, consolidating themselves as dominant by isolating her as outcast.

The phrase "other side" first occurs in Lady Oracle when the adolescent Joan begins attending the quasi-religious services at the Jordan Chapel, and in this context designates a community of benevolent and vaguely protective ghosts. Joan, however, immediately recognizes the vulnerability inherent in becoming the object of even such spiritual mass scrutiny: 
I read two of the hymns, at random. One was about a joyous boat ride across a river to the Other Side, where loved ones were awaiting. The other was about the blessed spirits of those who've gone before, watching o'er us for our safety till we reach the other shore. This thought made me uncomfortable. Being told in Sunday school that God was watching you every minute of every hour had been bad enough, but now I had to think about all those other people I didn't even know who were spying on me. ${ }^{1}$

Here, as elsewhere, the view from Joan's side inevitably amounts to a vision of being "spied on." The side from which others watch and judge her is inevitably the side that puts her in the position of Other. In such applications of the metaphor of "sides," the emphasis falls on the enormity of the gap between self and others. For instance, in the opening of the novel Joan regretfully imagines an ad hoc community made up of the people from whom she has fled, all of them now inhabitants of an unattainable other side: "I closed my eyes: there in front of me, across an immense stretch of blue which I recognized as the Atlantic Ocean, was everyone I had left on the other side. On a beach, of course; I'd seen a lot of Fellini movies. The wind rippled their hair, they smiled and waved and called to me, though of course I couldn't hear the words" (p. 5). Although the Fellini paradigm (the reference is most obviously to $8^{x / 2}$ ) gives this scene a sort of benignant dottiness, the same paradigm emphasizes the alienation of Joan from the group she has envisioned. No matter how affectionately its members appear to regard her, they are too far away to include her. Later Joan returns to the Felliniesque beach to record her nostalgia for her husband, Arthur, and the separating ocean becomes the passage of time: "the future swept over us and we were separated.... He was moving at an ever-increasing speed away from me, into the land of the dead, the dead past, irretrievable" (pp. 148-49). The vast and unbridgeable nature of the distance between herself and the others finally counters the appearance of affection, becoming a figure first for estrangement and then for opposition. The most important illustration of this tendency is again her relationship with Arthur, which begins with his high-minded lack of interest in any of the activities of her daily

${ }^{1}$ Margaret Atwood, Lady Oracle (New York: Avon, 1976), p. 115, hereafter cited parenthetically in the text. 
life, to the point where he is ignorant both that Joan spends her days writing "costume Gothics" and that she supports them both by doing so, then moves to his embarrassment when she becomes a publicly renowned "poetess" whose productions may cause people to think badly of him, then moves again to the suggestion of active menace when she begins to receive anonymous threats. But Arthur is to a certain extent only the most prominent of the male or maleidentified others in Lady Oracle who stand in opposition to Joan and who ignore, reduce, or rewrite her life to fit more socially sanctioned stories.

The presence of such isolating and estranging versions of the Other Side within the novel is one of the factors tending to subvert the most common reading of the novel, a reading that Joan herself seems eager to advance at certain points. This reading in effect reduces her long and intricately structured narrative to a psychological and moral fable, rooting all the conflicts of the story in her own inability or unwillingness to make separations and take sides. According to this intepretation, the signal problem leading to all other conflicts is her own failure to make the key distinction between self and other, a distinction that originates and is summed up in the distinction between self and mother. As Joan observes late in the story, she has "carried [her] mother around [her] neck like a rotting albatross" all her life (p. 238), and the admission is presumed to bring her to the point where she can choose individuation of a rather radical sort: "I would never be able to make her happy. Or anyone else. Maybe it was time for me to stop trying" (p. 363). This decision, when read as an efficacious declaration of independence from the obligation to make anyone happy, is seen as resolving the initial problem of inadequate individuation that has led her to create and sustain false selves modeled on the heroines of Gothic romance, all of whom she has been inclined to conflate with the real one. The resolution is regarded as especially therapeutic because confusion about the true borders of the self was ultimately manifested as an incapacity to differentiate among the worlds of fantasy, fiction, dream, and hallucination, on one side, and reality, on the other.

Rather paradoxically, this construction of the story requires that Joan obey her own self-admonishments "pull yourself together" and "contain yourself" by cutting herself down to size, identifying and 
getting rid of the false selves that act as surface excrescences and so peeling down to a presumptive core of authenticity. Analogously, this construction of the story requires the reader to pull the novel together by identifying and separating out the false portions: by assigning parts of the narrative to the "real" fictional world, parts to the "fictions" imbedded within the fiction, and parts to uncontrolled aspects of Joan's imagination-as Joan's dreams, hallucinations, or fantasies-out-of-control. ${ }^{2}$

By now, of course, this sort of reading ought to sound suspiciously pat as well as suspiciously familiar. To sketch only two of the most obvious problems, first, the kernel "self" that it presumes to be lurking underneath veils of imaginative falsity is at once so simple and so impervious to influence from the surrounding mass culture (a culture depicted in minute and hilarious detail) that it seems theoretically indebted to the paperbacks on popular psychology sharing the supermarket display racks with the "costume Gothics" that are explored and parodied in Lady Oracle. This psychologizing of the plot-an operation in which social inequities are reinscribed as conflicts within the same "self" that would otherwise be perceived as the victim of these inequities-is of course a familiar strategy for translating the political issues of gender oppression into the realm of self-help. Second, some of the values assumed by this kind of interpretation seem open to further question insofar as the incidents

${ }^{2}$ See especially Sharon R. Wilson, "The Fragmented Self in Lady Oracle," Commonwealth Novel in English 1 (January 1982), 50-85, where Joan is a "narcissistic personality" in opposition to a psychologically constructed (if nowhere present in Atwood's narrative) "normal self"; Frank Davey, Margaret Atwood: A Feminist Poetics (Vancouver, B.C.: Talonbooks, 1984), where Lady Oracle is "the story of how [Joan's] projections of Gothic malevolence and glamour onto everyday reality have prevented her from seeing the actual rewards and dangers of everyday" (p. 59); Sherrill Grace, Violent Duality: A Study of Margaret Atwood (Montreal: Vehicule Press, 1980), where "it may be true ... that all literature comes from other literature . . . but life does not, or should not, especially if that literature is Gothic romance" (p. 118, Grace's italics); Clara Thomas, "Lady Oracle: The Narrative of a Fool-Heroine," in The Art of Margaret Atwood: Essays in Criticism, ed. Arnold E. Davidson and Cathy N. Davidson (Toronto: Anansi Press, 1981), where Joan is "self-destructive" and must be educated "into individual and social responsibility" (p. 159); Catherine Sheldrick Ross, "Banished to This Other Place': Atwood's Lady Oracle," English Studies in Canada 6 (Winter 1980), where a strong analysis of structural analogues between frame and imbedded levels of plot is naturalized by being referred to "dangerous delusions" in which "Joan has been taken over by her shadowy twin" (pp. 469-70). 
to which they are supposed to apply occur within a work of fiction. For example, the creation of fictions becomes in this context a debased and unhealthy activity, both because it manufactures false selves and worlds, which must then be discriminated from the real or true ones, and because it is is associated with a lack of self-control: Joan's trancelike state when she touch-types her "costume Gothics" is a case in point. While Lady Oracle incorporates elements of many genres, it is certainly a Kunstlerroman, a portrait of the artist as a young woman, and as such resists the unequivocal privileging of a "real self" when one implied opposite is the persona created by the imagination and of a "real world" when one implied opposite is fiction.

More insidiously, this kind of reading involves what the preceding chapters imply are gender-coded assumptions about the representation of "woman" in fictional discourse and the representation of female authorship in critical discourse. Like many of the established readings of Jean Rhys's novels, it seeks to account for the rejection and humiliation of a protagonist by blaming her. Like many of the early readings of The Golden Notebook, it tries to naturalize "unrealistic," discrepant, or conflicting aspects of the discourse by declaring them "unreal" within the fictional context, conscious or unconscious projections of the protagonist's psyche. And like several influential readings of The Color Purple, it is inclined to view anomalies of plotting, in particular the anticlimactic conclusion, as flaws, indicators that in writing "a book that was all tangents" (as Atwood herself described Lady Oracle), ${ }^{3}$ the author was exceeding the boundaries of her own competence, which was far better displayed in the pareddown mastery of her preceding novel, Surfacing (1972).

But the view of Joan, and of Atwood, that this interpretation proposes is far too congruent with the dominant construction of "woman" within Western culture, in that woman's essential otherness is conventionally manifested in her culpability, her extravagance, and her need of constant control. If in many respects Lady Oracle actively invites the reductive reading sketched out here, it does so in a context that makes reduction a particularly problematic concern for women. Most obviously, this is a book in which fat is

\footnotetext{
${ }^{3}$ Interview with Atwood, quoted in Jerome H. Rosenberg, Margaret Atwood (Boston: Twayne World Authors Series, Canadian Literature, 1984), p. 112.
} 
a feminist issue, and in which excess of body becomes symbolic of female resistance to a society that wishes to constrict women to dimensions it deems appropriate, using devices that range from exemplars to definitions to diets. More generally, this is a book in which the activity of marking limits and designating "sides" is at once a social imperative and an ontological impossibility. Despite a pervasive rhetoric of self-help, in which control and containment are the approved outward and visible signs of a valorized "secure" identity, the fictional universe of Lady Oracle is one in which things do not always stay in their places. In particular, boundaries between self and other and between reality and unreality can shift or even dissolve without warning.

The two "sides" occupying the most space in Lady Oracle are the universe of the "costume Gothics" that Joan writes under the pseudonym of her late, beloved Aunt Louisa K. Delacourt and the adjacent universe of the contemporary "reality" that Joan inhabits along with such characters as her mother and father, Miss Flegg of the dancing school, the malevolent Brownies, the teenage vamps who grow up to become the implied readers of her "costume Gothics," the Canadian nationalists who want to blow up the Peace Bridge, the Polish Count, the Royal Porcupine, the poet and blackmailer Fraser Buchanan, and of course her husband, Arthur. The second catalogue suggests that despite Joan's assertions to the contrary, "reality" in this novel is no more "gray and multi-dimensional and complicated" (p. 300) than the world occupied by Charlotte, Felicia, and Redmond of the imbedded romance Stalked by Love or, for that matter, than the world occupied by the Lady who in the imbedded poem, "Lady Oracle," "floats down the river / singing her last song" in free-verse imitation of Tennyson's Lady of Shalott (p. 252). Joan herself is concerned to separate her own life from the garish and violent plots that engage her heroines, but the (highly conventional) distinction she wants to invoke between art and life never quite applies to the situation at hand. For instance, reflecting on the demands of her married female friends, she decides that her 
own double role as public drudge and closet fantasist is a more practical solution to the problem of female heterosexual desire:

They wanted their men to be strong, lustful, passionate and exciting, with hard rapacious mouths, but also tender and worshipful. They wanted men in mysterious cloaks who would rescue them from balconies, but they also wanted meaningful in-depth relationships and total openness. (The Scarlet Pimpernel, I would tell them silently, does not have time for meaningful, in-depth relationships.) They wanted multiple orgasms, they wanted the earth to move, but they also wanted help with the dishes. [p. 241]

The men with "hard rapacious mouths" and the men who offer "meaningful in-depth relationships" are clearly products of very different discursive codes. Precisely because the codes are so recognizable as codes, however, the designations "art" and "life" are inadequate to characterize them. Both kinds of men are familiar constructs, which is to say that both belong to the domain of art, or at least of artifice. Both occur in mass-market publications, albeit publications with very different controlling premises, and both kinds of publication presume the same general reading public: middle-toworking-class dissatisfied women. ${ }^{4}$ Atwood juxtaposes the banalities of popular psychology and of self-help guides ("total openness," "help with the dishes") with the banalities of popular romance ("mysterious cloaks," "they wanted the earth to move"), thereby pointing up the socially constructed and manipulative nature of both genres. By implication, it is not "reality" that dictates a radical split between female eroticism and daily life, but the whole of a consumer culture that relegates women's sexual desire to the domain of the fantastic and so curtails "woman" as she is "realistically" represented.

In this way the primary distinction, to which Joan periodically reverts, between the "side" of the real world and the "side" of the fictional or fantastic world, is made problematic by the derivative nature of all Joan's experience. Lady Oracle is a highly satirical novel,

${ }^{4}$ Two recent and (largely) sympathetic studies of popular fiction for women and its implied and real readers are Tania Modleski, Loving with a Vengeance: Mass-Produced Fantasies for Women (New York: Methuen, 1982); and Janice A. Radway, Reading the Romance: Women, Patriarchy, and Popular Literature (Chapel Hill: University of North Carolina Press, 1984). 
and the satire results not from an invasion of the real by the conventions of the artificial but from the clash of conventions belonging to different discursive practices. If incursions of rhetoric from Gothic novels or Italian fotoromanzas or cautionary-tale structures from such fairy stories as "The Little Mermaid" and "Bluebeard" or from such movies as The Red Shoes seem to signal that a passage is informed by Joan's fantasies, inasmuch as these cues reveal her psychic indebtedness to the formative fictions Western culture has produced for women, the conventions by which she is presented to the reader are similarly drawn from familiar models and similarly imbued with ideological presuppositions. Lady Oracle is not a novel in which the costume Gothic stands in clear opposition to the naked truth. In the imbricated worlds of this story, both clothing and nudity are acknowledged to be already coded within a number of different sign systems.

In similar ways, conventions governing appearances of the supernatural in the Gothic seep into the "real" world of Toronto and environs, with generally unsettling effects. Indeed, in many ways the function of the supernatural in Lady Oracle is the reverse of the function of the supernatural in the traditional Gothic, where occurrences that throughout the story appeared inexplicable from the point of view of contemporary science turn out at the conclusion to have mundane and, as a consequence, deflating explanations. For example, in the great Gothic prototype Ann Radcliffe's Mysteries of Udolpho, the central monitory figure, the apparent ghost of a woman who died because of her sexual transgressions, turns out to be a living woman whose "haunting" of the castle is a consequence of her insanity. ${ }^{5}$ Claire Kahane sees in such veiled but curiously central female figures, who seem at the emotional core of all Gothics, "the spectral presence of a dead-undead mother, archaic and encompassing, a ghost signifying the problematics of femininity which the heroine must confront." ${ }^{\prime \prime}$ The conventional Gothic conclusion thus naturalizes the supernatural and renders the archaic mother harmless because illusory, unambiguously Other and thus no longer a

${ }^{5}$ Ann Radcliffe, The Mysteries of Udolpho (Oxford: Oxford University Press, 1966).

${ }^{6}$ Claire Kahane, "The Gothic Mirror," in The (M)other Tongue: Essays in Feminist Psychoanalytic Interpretation, ed. Shirley Nelson Garner, Claire Kahane, and Madelon Sprengnether (Ithaca: Cornell University Press, 1985), p. 336. 
threat to established boundaries, no longer an uncanny mirror reflecting self as other and making other eerily recognizable as self.

Kahane's feminist psychoanalytic reading of Gothic conventions clearly has applications to the self/(m)other drama in Lady Oracle, in particular because it suggests that individuation can never be an unproblematic concept for women. If the male child can use the fact of his sex to declare his fundamental difference from the mother who was initially his point of contact with the world, "the female child, who shares the female body and its symbolic place in our culture, remains locked in a more tenuous and fundamentally ambiguous struggle for a separate identity. ${ }^{\prime 7}$ For a female child, to separate from the mother is to renounce what may be the only possible source of female power, a power at once more threatening and more seductive because it involves notions of merging and obliteration, effacement of the limits with which patriarchal culture constructs and maintains its world. And as Kahane points out, the Gothic heroine gains her separate self only to lose it in a concluding heterosexual marriage. The supernatural yields to the natural; the mother yields to the husband; the Gothic protagonist has flirted with sexuality and power only to be safely reinscribed in the romance plot. Kahane summarizes her experience in reading Udolpho:

Thus the novel allows me first to enjoy and then to repress the sexual and aggressive center of Udolpho, which, as the mad nun has warned, leads to madness and death, and leaves me safely enclosed-but, significantly, socially secluded-in an idealized nurturing space, the space provided for heroines by patriarchal narrative convention. ${ }^{8}$

Atwood is of course well aware of the founding presuppositions of the Gothic. Her projected doctoral dissertation at Harvard, which was to be titled "The English Metaphysical Romance," was to concentrate particularly on defining structural aspects of the genre, and her remarks during interviews affirm that she was one of the earliest researchers to see the importance of the Gothic as a preeminently female form. ${ }^{9}$ Lady Oracle is preoccupied both with the Gothic and

7'Ibid., p. 337 .

${ }^{8}$ Ibid., p. 340.

${ }^{9}$ Davey, Margaret Atwood, p. 12. Atwood speaks extensively about Gothics in Cathrine Martens, "Mother-Figures in Surfacing and Lady Oracle: An Interview with Margaret Atwood," American Studies in Scandinavia 16 (1984), 45-54. 
with the female body, a conjunction of concerns suggesting a "sexual and aggressive center" that will be treated more self-consciously, perhaps even inscribed in an altogether different register in this novel.

The supernatural events in Lady Oracle invariably take the form of appearances of a female body. This body is always aligned with the maternal, most obviously in the case of Joan's own mother, who makes her spectral appearances costumed in the period garments of the feminine mystique that entrapped her. In her first manifestation she is seen not by Joan but by the self-styled medium Leda Sprott, who runs the Jordan Chapel and who describes the woman standing behind Joan's chair as "about thirty, with dark hair, wearing a navy-blue suit with a white collar and a pair of white gloves" (p. 120). In the context of the seedy service that Joan is attending for the first time, this appearance seems part of the ongoing complicity between Leda Sprott and her elderly, scatty congregationexcept, of course, that as Joan observes, there is no reasonable explanation for the fact that Leda Sprott knows what her mother looks like. When pressed with the information that this ghost has "broken the rules," Leda offers the hypothesis of an "astral body," which "could float around by itself, attached to you by something like a long rubber band" (p. 121), an explanation that does nothing to make the phenomenon more immediately credible but that remains uncontested throughout the narrative (except by Joan's initial "That's crazy") for lack of a more plausible theory.

This particular manifestation of Joan's mother recurs two more times in the course of Joan's narration. In the first, Joan returns to the London apartment of her new lover Arthur and his two roommates to discover her mother standing there, dressed in her 1949 navy blue suit, hat and gloves, wearing her 1949 Joan Crawford makeup, and "crying, soundlessly, horribly; mascara was running from her eyes in black tears." Despite the accumulation of detail, there is no question of this woman's being physically present in the London flat: "Through her back I could see the dilapidated sofa; it looked as though the stuffing was coming out of her" (p. 194). Five days later, Joan receives the telegram announcing her mother's death and realizes "she'd turned up in my front parlor to tell me about it" (p. 196). The last time this mother appears, she wears the same 
clothing and makeup and is crying the same mascaraed tears, but this time her behavior suggests a mother-daughter role reversal as well as alluding to the frame tale of another formative Gothic, Wuthering Heights: ${ }^{10}$

She was crying soundlessly, she pressed her face against the glass like a child, mascara ran from her eyes in black tears.

"What do you want?" I said, but she didn't answer. She stretched out her arms to me, she wanted me to come with her; she wanted us together. [p. 362]

Here the spectral mother almost lures Joan off her balcony ("She'd come very close that time, she'd almost done it," Joan reports [p. 363]), and the incident provokes the recognition "I would never be able to make her happy. ... Maybe it was time for me to stop trying" (p. 363). Clearly the manifestations of the mother's "astral body" represent occasions for Joan to confront the complexity of her relationship to her mother and to separate herself from the impossible task of making her happy.

But confrontation and separation do not serve to naturalize these manifestations. The mother's repeated incursions into the banal "reality" inhabited by Joan remain supernatural, despite their therapeutic function. They cannot be explained, for instance, as fantasies generated by Joan's obsession with pleasing her mother: the first "astral" appearance is witnessed not by Joan but by Leda Sprott, and the second occurs before Joan has any notion that her mother has died. These semiparodic, semiserious visitations remain detached from any sort of explanatory structure that would integrate them into a coherent, fundamentally realist fictional universe. They are indicative of a tendency on the part of the female body in this novel to turn up unexpectedly and inexplicably, to transgress the limits that have been set for it, to refuse to stay in its place.

Another important manifestation of this tendency is the Fat Lady, who is at first, at least apparently, an imaginative construct based on the memory of too much flesh, which haunts Joan as a sort of

${ }^{10}$ The occasion for Lockwood's hearing the story of Cathy and Heathcliff from Nellie Dean is the spectral appearance of the child Cathy outside Lockwood's window crying, "Let me in-let me in!" Emily Brontë, Wuthering Heights (New York: Macmillan, 1929), p. 24. 
ghostly residue of her overweight childhood. The effect of losing a hundred pounds after reaching physical maturity was to make Joan sexually desirable for the first time, while simultaneously stripping her of the enveloping flesh that had symbolized her resistance to the societal norms her mother was trying to impose and that had served, albeit ironically, as a source of power. Reminiscing about the way her size had buffered her from "the usual female fears," Joan observes that to molest her would have been "like molesting a giant basketball," and adds, "Though I treasured images of myself exuding melting femininity and soft surrender, I knew I would be able to squash any potential molestor against a wall merely by breathing out" (pp. 155-56). The process of reducing began to expose her to sexual depredations: "Strange men, whose gaze had previously slid over and around me as though I wasn't there, began to look at me from truck-cab windows and construction sites; a speculative look, like a dog eyeing a fire hydrant" (p. 135). Atwood's representation of the consequences attendant on a dramatic change in body size reveals graphically that for a woman in Western society, to be perceived as sexual is to be a potential victim.

Joan comes to realize that her fat had provided a "magic cloak of blubber and invisibility" (p. 157), which had not only protected her from unwelcome advances but had allowed her to observe the social world of her age group and to arrive at some acute insights about the women who would make up her reading public. On the other hand, this peculiar invulnerability was also construed as asexuality. "Though immersed in flesh, I was regarded as being above its desires, which of course was not true" (p. 102), she reports, marking in passing one of the most characteristic features of femininity as it is currently constructed-a tenet at the heart of such cultural myths as the story of the Little Mermaid or the film The Red Shoes and one of the precepts subjected to the closest scrutiny in this novel. This tenet prescribes amputation as the defining feature of female existence: getting one thing always involves giving up another. As Joan summarizes the rule, "In order to get a soul you had to suffer, and you had to give something up; or was that to get legs and feet? I couldn't remember. She'd become a dancer, though with no tongue. Then there was Moira Shearer, in The Red Shoes. Neither of them 
had been able to please the handsome prince; both of them had died" (p. 241).This formulation points up how whimsical the imperative is to choose between such evidently compatible desires as artistic creation and heterosexual love. As the plot nears its climax, however, Joan realizes that she has not been able to evade the prescription after all, and the bifurcation is revealed as not only arbitrary but damaging: "You could dance, or you could have the love of a good man. But you were afraid to dance, because you had this unnatural fear that if you danced they'd cut your feet off so you wouldn't be able to dance. Finally you overcame your fear and danced, and they cut your feet off. The good man went away too, because you wanted to dance" (p. 368).

The image of the Fat Lady that she concocts seems a response to the discovery that society requires women to be maimed to be acceptable and that even a maimed woman may not be sanctioned if her desires are considered too disruptive. The Fat Lady, as Joan conceives her, is the embodiment-literally-of the female potential for excess, of the threat that unmutilated, unchecked femininity will overflow boundaries, obliterating distinctions and violating proprieties. Significantly, she is a circus freak, a spectacle, "something that had to be seen to be believed" but that Joan is not allowed to view. Even more significant, she arises from Joan's conflation of two forbidden sideshow attractions, one featuring the traditional Fat Lady and a second featuring dancing girls in gauze pants and maroon satin brassieres (p. 97). Not only is this Fat Lady surpassingly large-Joan imagines her "fatter than the crude picture of her painted on the hoarding, much fatter than me" (p. 111) - but she is also one of her culture's avatars of active yet sexually desirable femininity, a dancer who in her second appearance wears the tiara and the pink ballerina's tutu that Joan craved as a child. Joan finds her own fantasy inappropriate, inasmuch as it seems to defy the popular platitudes about "accepting oneself" that she imagines issuing from Arthur:

What a shame, he'd say, how destructive to me were the attitudes of society, forcing me into a mold of femininity that I could never fit, stuffing me into those ridiculous pink tights, those spangles, those outmoded, cramping ballet slippers. How much better for me if I'd been 
accepted for what I was and had learned to accept myself, too. Very true, very right, very pious. But it's still not so simple. I wanted those things, that fluffy skirt, that glittering tiara. I liked them. [p. 112]

Paradoxically, these pieties about self-acceptance only confirm that Joan herself is not acceptable, precisely because she wants too much. Her "self" exceeds the requisite ideological containers.

As the plot develops, the Fat Lady becomes excessive in other respects, intruding herself into the action in ways that are less and less reconcilable with the premise that she is Joan's fantasy. As if she has irremediably forgotten her place, she finally emerges unheralded and unanticipated in the middle of that Canadian national ritual of male bonding, a hockey game, which Arthur is watching on television: "The Fat Lady skated out onto the ice. I couldn't help myself. It was one of the most important moments of my life, I should have been able to keep her away, but out she came in a pink skating costume, her head ornamented with swan's-down" (p. 304). At this point, when Joan is contemplating the necessity of telling Arthur about one of her "other" lives, the Fat Lady figures simultaneously as a sign of Joan's lack of self-control and as a character who has become autonomous to the point where she herself is violating both social and textual prohibitions. As Joan watches, the Fat Lady floats to the top of the screen like a helium balloon and remains there.

The U.S. team scooted across the bottom of the screen like a centipede, but no one paid any attention, they were all distracted by the huge pink balloon that bobbed with such poor taste above their heads.... The Fat Lady kicked her skates feebly; her tights and the huge moon of her rump were visible. Really it was an outrage. "They've gone for the harpoon gun," I heard the commentator say. They were going to shoot her down in cold blood, explode her, despite the fact that she had now burst into song.... [pp. 305]

Like all the Fat Lady episodes, this passage incorporates important elements of Joan's previous experience: the "huge moon of her rump" offering a target to the harpoon gun recalls the conjunction of events involving Aunt Lou's mysterious death and Joan's wounding by a prankster's arrow; "she had now burst into song" brings together a complex of allusions to singing, which figures in this 
novel both as an expression of agony and as a paradigm of art, ${ }^{11}$ and here is explicitly aligned with death (albeit in a fairly ludicrous context) because of its association with the Disney cartoon The Whale Who Wanted to Sing at the Met. But this implicitly climactic manifestation of the Fat Lady makes an incision within the "reality" of Joan's fictional universe. Whereas the Fat Lady was previously identified as a fantasy, she has now gone beyond Joan's management to the point where such apparent inhabitants of the gray and multidimensional world as the television commentator are so distracted by her extravagant otherness that they are attempting to destroy her. Yet this scene can also be read as the production of Joan's involuntary imagination, as a full-scale hallucination, for Arthur continues to watch stolidly, his gaze relegating this exorbitant Other and all the confusion she generates to the side of the unreal.

Arthur's gaze here acts as agent of the naturalizing impetus within the narrative, denying visibility to the spectacular by assigning it a psychic and indeed a pathological origin. Not coincidentally, naturalization of this sort is always a male move in Lady Oracle, while the tendency to see something instead of nothing is female. The body of the Fat Lady, like the "astral body" of Joan's mother, is a figure for the other "selves" that Joan-and other women as wellinhabit because the social definition of "woman" is too constricted to accommodate them. Such bodies are also surplus that the realist narrative cannot accommodate, representations of "woman" that exceed the patriarchal gesture whereby the real is defined and contained. Like the Fat Lady at the hockey game, they bob disconcertingly above the "real" action, distracting attention despite the masculinist insistence that there is "really" nothing to be seen.

II

Lady Oracle is concerned with how the female body, as a figure for female desire, becomes both spectacular and invisible within a cul-

${ }^{11}$ One of the most poignant passages making this association occurs early in the narrative, when Joan recalls wanting to be an opera singer: "It always appealed to me: to be able to stand up there in front of everyone and shriek as loud as you could, about hatred and love and rage and despair, scream at the top of your lungs and have it come out music" (p. 83). 
ture wishing to restrict the "real" to masculinist desire and its objects. The phrase nothing to be seen is particularly resonant in this context of curtailing or dismissing the female body because of its centrality in Freud's account of the castration complex. According to Freud, this complex arises from the little boy's (and, symmetrically, the little girl's) discovery that the mother does not have a penis. But the assumption that the absence of a penis leaves "nothing" visible seems already implicated in an ideology in which only some "things" count as existents. As Luce Irigary observes in her monumental critique of the Western philosophical tradition, Speculum of the Other Woman, Freud's translation of "no penis" into "no thing" amounts to a leap into the universal that is paradigmatic of a discourse founding itself on the unicity and centrality of the phallus. "Nothing to be seen is equivalent to having no thing," Irigaray writes. "No being and no truth."12 That is, the judgment "nothing to be seen," imposing as it does the primacy of the visible, the unitary, the monolithic embodied in the phallus as sex-as the only possible sex organ and therefore as the only possible mark of sexual identity-establishes woman in this discourse as possessor of no-thing; and thus as non-sex, as non-being, as deficiency, as object against which the subject asserts himself and into which, conveniently, he inserts himself. ${ }^{13}$

It is important to note that the discourse in which this judgment, nothing to be seen, finds its place is not limited to psychoanalysis. If Irigaray begins Speculum of the Other Woman with a reading of Freud on feminine sexuality, she does so because she finds his writing particularly illustrative of the ways in which difference is absorbed into what she terms the economy of the Same, the entirety of the dominant culture, inasmuch as this culture constructs Others by excluding them. One of her more violent formulations, "The slit is sewn up," illustrates how more-than-one-thing - the labia of the vagina, to cite her most famous example-must be forcibly reduced to no-thing if this economy is to function.

\footnotetext{
${ }^{12}$ Luce Irigaray, Speculum of the Other Woman (Ithaca: Cornell University Press, 1985), p. 48 .

${ }^{13} J a n e$ Gallop points out that centering sexuality exclusively on the phallus points up the constructed nature of masculine sexuality as well. See her essay "Quand Nos Lèvres S'Ecrivent: Irigaray's Body Politic," Romanic Review 74, no. 1 (1983), 78-79.
} 
The more general issue for Irigaray is the philosophical problem called the One and the Many, and the discourse in question in Speculum is, rather alarmingly, the entirety of Western intellectual history. Irigaray goes on to suggest in her readings of Plato, Aristotle, Descartes, Kant, Hegel, and perhaps most insidiously, in the excerpt from Plotinus's Enneads, which is quoted without comment, that the "problem" of the One and the Many in this tradition has traditionally been the problem of getting the Many subsumed under the One before they cause any trouble, preferably as some version of NoThing into which the One can comfortably fit itself. Female genitals, and indeed the polymorphous character of female sexual experience, ${ }^{14}$ become in this discussion a site of difference, an insinuation of otherness figured most subversively as the "other woman" wedged into the interstices of an apparently monolithic discourse. The problem of writing about difference, specifically about female sexual pleasure, here becomes emblematic of the problem of writing difference, writing differently, outside of or alongside of or in the gaps within the dominant discourse. Irigaray asks how the woman of Freud's master narrative is to find "symbols for the state of 'this nothing to be seen,' to defend its goals, or to lay claim to its rewards. Here again no economy would be possible whereby sexual reality can be represented by/for women." 15 Yet the impossibility is precisely a function of a masculinist "economy" defined (by its upholders) as completely coherent, subject to no dispersal, no irreconcilable differences between the systems-or stories-that compose it. Later she asks, "But what if the 'object' started to speak? ... What disaggregation of the subject would that entail?"'16 The question has provoked enormous controversy because it seems to imply contradictory activities: giving voice to silence, articulating the formless void that is no-thing.

A number of theorists have accordingly concluded, given this account of the operation by which the dominant culture constitutes "woman" as so radically Other that her difference amounts to non-

\footnotetext{
${ }^{14}$ According to Gallop, "the multiplicity of female genitals [is] a textual production" and not a biological "fact," but Irigaray's writing uses this production to create a "referential illusion" of polyvocality that has "a surprising, vulgar political efficacy" (pp. 79-80).

${ }^{15}$ Irigaray, Speculum, p. 49 (Irigaray's italics).

${ }^{16}$ Ibid., p. 135.
} 
existence, that asking "woman" to speak entails a logical impossibility. Shoshana Felman states the problem succinctly: "If 'the woman' is precisely the Other of any conceivable Western theoretical locus of speech, how can the woman as such be speaking in this book?"17 Of course, Felman's formulation "any conceivable Western theoretical locus of speech" is hyperbolic, in that Irigaray's project is precisely to conceive other-wise; and to note the hyperbole is to point up the answer to a question that is not, after all, merely rhetorical. In Irigaray's writing, the economy of the Same is not monolithic; the codes or narratives making up Western culture are not joined seamlessly, and as a consequence, what is outside is not always unambiguously dismissable as silence or no-thing. There is always the possibility of speaking through the gaps, of exploiting the contradictions within a system that cannot afford to acknowledge its own self-division.

Irigaray's own gestures and especially her own practice in Speculum and such later productions as "When Our Lips Speak Together" suggest how the ostensible "silence" to which "woman" is relegated might turn into a voice. If there can be no clearly delineated Other language, no direct route to the articulation of difference, it follows that difference must use the language of the Same-if rather differently. That is, representation must be skewed or oblique, a perverse mimesis employing the sort of concave mirror that is the primary image of the speculum for Irigaray, the mirror that inverts the image as a condition of reflecting it. Mimesis as mimicry; representation with a difference. The method of Speculum of the Other Women suggests that one means to this end is a miming of the phallocentric discourse of the dominant culture and that through emphasis and through pursuit of implications to a reductio ad absurdum such a miming can allow readers to glimpse the motivating force that keeps this discourse entire and returning on itself. A second means to this end might well be a miming of the feminine as deficiency, as an otherness claimed to be the necessary supple-

\footnotetext{
${ }^{17}$ Shoshana Felman, "The Critical Phallacy," Diacritics 5 (Winter 1975), 2-10. Barbara Godard also raises this point with respect to Lady Oracle in a brilliant and significantly nonreductive essay, "My (M)other, My Self: Strategies for Subversion in Atwood and Hébert," Essays on Canadian Writing 26 (Summer 1983), 13-44. See also Roslyn Belkin, "The Worth of the Shadow: Margaret Atwood's Lady Oracle," Thalia 1, no. 3 (1979), 3-8.
} 
ment to masculine sufficiency. By and large, this is the method of Freud's celebrated hysterics. Irigaray's analysis indicates that it may be the method of "other women" as well.

For the question about whether it is possible to write difference ought to lead irresistibly to a second, more pragmatic question: if difference were written, could anyone see it? This whole book begins from the premises that there are women writers who perceive the discourse into which they are, willy-nilly, inscribed as radically gendered; who have perceived themselves as in some respects ill fitted for or poorly inserted into the economy of the Same; who have attempted to write about sexual difference from and within this economy; and who in the process have attempted to adapt the language to their own uses-to write differently. For all the authors under consideration here, writing difference has involved a degree of mimicry that becomes politically significant inasmuch as it diverges from its purported models, becomes representation with a twist. The example of Lady Oracle raises the question in its most problematic form because in the narrative voice of this novel Atwood deliberately apes the culturally constructed "feminine," an activity that Sandra Gilbert has termed "female female impersonation." 18

For example, in the opening of the novel, Joan is engaged in the anomalous enterprise of narrating in the past tense the events leading up to her own death:

I planned my death carefully; unlike my life, which meandered along from one thing to another, despite my feeble efforts to control it. My life had a tendency to spread, to get flabby, to scroll and festoon like the frame of a baroque mirror, which came from following the line of least resistance. I wanted my death, by contrast, to be neat and simple, understated, even a little severe, like a Quaker church or the basic black dress with a single strand of pearls much praised by fashion magazines when I was fifteen. [p. 3]

\footnotetext{
${ }^{18}$ Sandra Gilbert, "Female Female Impersonators: The Sardonic Heroinism of Edna St.-Vincent Millay and Marianne Moore" (lecture, Cornell University, 23 March 1986). Mary Russo glosses, "If hysteria is understood as feminine in its image, accoutrements, and stage business (rather than in its physiology), then it may be used to rig us up (for lack of the phallic term) into discourse" ("Female Grotesques: Carnival and Theory," in Feminist Studies: Critical Studies [Bloomington: Indiana University Press, 1986], p. 223).
} 
But any sense that the situation of posthumous narration presents a genuine mystery requiring serious elucidation is immediately countered by the voice of the narrator. In fact, this narrator is so recognizable and so conventional in function that her very presence at first seems sufficient to deflate and neutralize serious questioning. She belongs in the tradition of Lucille Ball or Gracie Allen, or in the realm of authorial personae, someone like Jean Kerr or Erma Bombeck. Her characteristic tone is rueful but fatalistic-silly me, I always mess up-for this is that great comic figure the castrated woman, woman as wholly and ludicrously other, woman with-and asnothing to be seen. Yet the construction of reality that renders her invisible also requires her to be a spectacle-as she must be in order to reenact the endless drama of her identity, in which she comes up yet another time against the recognition of her own nature as deficiency or lack-specifically as deficiency or lack of control. Here, very clearly, what is missing is a principle of containment, something that will keep the speaker in one piece. In this opening passage, Joan has announced her failure of integrity in the root sense: she is for some curious reason unable to stay together.

Her retrospective narration goes on to chronicle how she grew up by multiplying into separate "selves," beginning from the experience of becoming "a different person" after her weight loss, a process of acquiring "the right shape" that involved discovering she now had "the wrong past" (p. 157). She discovered that this dwindling into femininity required her to diminish herself further by choosing an already-established role, an act that required amputating not only "the wrong past" but great portions of the present as well. In dealing with Arthur's roommates, for example, she learned, "One could not, apparently, be both a respected female savant and a scullery maid" (p. 190), and fearing that her "costume Gothics" made her intellectually unrespectable in Arthur's eyes, she in effect chose the scullery maid role in his presence, playing the devoted if inept wife and turning out the pages only when he wasn't looking. The seductions of the Gothic in turn led her to locate a third "self," whose unconscious existence at the heart of the self/(m)other labyrinth became the impetus for still another kind of secret-albeit stereotypically "feminine"-writing. This figure came into being as Joan pieced together words she had written during passages of self- 
hypnosis. Joan enters the subterranean region of this "lady oracle" through a mirror, itself a duplicate of the three-sided dressing table mirror of her childhood that revealed her mother as hydra-headed, uncontrolled, "a monster" (p. 70). The device of the mirror as entry suggests that the powerful, unhappy, somehow maternal persona of the poem is the reverse or repressed side of the "happy and inept" persona (p. 248) that Joan allows herself and is allowed by the society represented most powerfully by her husband, the selfstyled political radical whose entire mode of functioning presumes her continued presence as a "nourishing blob" (p. 236).

Yet the narrative voice presents this socially mandated disintegration largely as a failure of self-containment, one that implies other breaches of integrity, to which Joan will also admit, ruefully. For instance, she confesses to being chronically dishonest, at first unwilling to tell the truth because of her perception of the probable consequences-“'In my experience, honesty and expressing your feelings could lead to only one thing. Disaster" (p. 37)-but later, and worse, unable even to identify "the truth" among so many plausible contenders. Reporting on the Polish Count's accusation that she had a lover, she confides ingenuously, "I'd always found other people's versions of reality very influential and I was beginning to think that maybe he was right, maybe I did have a secret lover" (p. 180). Here, as elsewhere in the narrative, "other people's versions of reality" are more conventional and more coherent than her own, and the demands that she be conventional and coherent tend to act as regulatory principles prompting her to condemn her own story for its exuberance. But she also draws from the experience the correct lesson: the problem is not that she tells lies, but that her lies are not in accordance with current norms of realism, not in the most ordinary sense credible. As she admits, "I told lies but they were not watertight. My mind was not disciplined, as Arthur sometimes pointed out" (p. 170). Indeed, she interprets all her imaginative productions-lies, fantasies, dreams, hypnotic journeys, poetry and "costume Gothics" - as evidence of an essential lack, an absence that manifests itself as a plenitude, a superabundance of things that must be continually reconstrued as no-thing.

By her own account, then, the deficiency to which Joan so cheerfully admits resides in her excessiveness. Excess as deficiency is a 
paradox, of course, but it is a paradox familiar to any woman who has been schooled in the rigorous requirements of femininity. To take one example, the basic black dress with the single strand of pearls invoked at the opening of the novel is a classic emblem of feminine restraint that is also a class marker. The women who are the most valuable commodities in Joan's society are got up in this reticent style, whereas less costly women tend to be tricked out in the spangles and gaudy colors that Joan herself favors. The heroines of the mass-market novels that she writes (the name "costume Gothics" reflects her strong sense of the priority of clothing in the sign system in which where she herself is inscribed) also favor restraint, as opposed to the counterpoised bad women, whose badness is figured precisely in the fact that they, like Joan, cannot contain themselves. The two opposed female characters in her costumeGothic-in-progress Stalked by Love illustrate her mastery of the masculinist code whereby containment of the feminine translates into (among other things) sexual desirability:

He was thinking of Charlotte. He liked making her blush. He'd become tired of the extravagance of Felicia: of her figure that spread like crabgrass, her hair that spread like fire, her mind that spread like cancer or pubic lice. "Contain yourself," he'd said to her, more than once, but she couldn't contain herself, she raged over him like a plague, leaving him withered. But Charlotte now, with her stays and her peculiar ways, her white flannelette face, her bleached fingers ... her coolness intrigued him. [p.351]

Not surprisingly, the rampant Felicia looks a great deal like Joan, who manipulates the formulaic phrases of her genre in a fairly uncontrolled way herself, touch-typing with her eyes closed and so mimicking a prevailing ideology. But her own mastery of the formulas continually reminds her that she is not living up to expectations.

Her whole history, of course, is one of not living up to expectations by dint of being far more than what is required, even though she generally exceeds demands precisely because of her desire to please. For instance, the poem resulting from her experiments with automatic writing, "Lady Oracle," is described by variously enthusiastic and appalled male characters as "a cross between Kahlil Gibran and Rod McKuen" (pp. 250, 265), and the account of its reception suggests that in her possession of a truly mass-market unconscious Joan 
has once again became too much of a good thing, ultimately monstrous in her naive ability to outdo her ostensible creators, the press agents and publicists who cater to public appetites. All such excesses are presented as displacements of the excess of body that characterized Joan as a child. As a child, she ate not only to triumph over a mother who quite literally embodied the societal norm but also in an attempt to translate herself out of the realm of contingency, to guarantee her existence by overflowing assigned boundaries to become "solid, solid as a stone so she wouldn't be able to get rid of

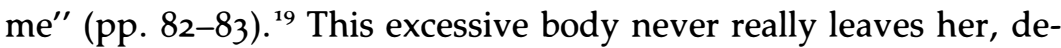
spite a precipitate weight loss; or rather, she does not lose her boundless body so much as gain a plurality of bodies, chief among them the spectral mother and the Fat Lady. These bodies function as weirdly corporeal alter egos, haunting her when she tries to confine herself to a single slender identity.

The discussion in the previous section has suggested some of the ways in which these bodies progressively elude her control, finally escaping beyond the naturalizing powers of the realist narrative. In a similar manner, aspects of the ostensibly "controlling" plot are infiltrated by apparently discordant elements of the Gothic in ways that cannot be explained simply by a tendency on the part of the narrator to see the "real" world through Gothic lenses. The most important instances occur near the end of the narrative, when Joan, who is becoming increasingly anxious because of the pressure of keeping her three identities separate, breaks off her relationship with the Royal Porcupine and begins to receive heavy-breathing telephone calls and to find dead animals with threatening messages attached to them lying on her doorstep. At first she attributes these memento mori to her rejected lover, who after all has to his credit an exhibition of frozen road kills. Then she suspects her erstwhile blackmailer Fraser Buchanan. But both men are convincing in their denials, and neither has any obvious reason for menacing her in this way. Mulling over the clues, she considers, "Perhaps one person

\footnotetext{
${ }^{19}$ In Lady Oracle, Atwood offers one of the first feminist analyses of obesity as an implicitly political response to social demands on women. Kim Chernin builds on this analysis in The Obsession: Reflections on the Tyranny of Slenderness (New York: Harper Colophon Books, 1981). See also Susie Orbach's landmark work on female body image, Fat Is a Feminist Issue (New York: Berkley, 1978).
} 
was doing the animals, another the notes, a third the phone calls ... but I couldn't believe that. It had to be a single person, with a plan, a plot that had some end in view" (p. 325). The hypothesis of a single agent and a single plot is rooted in literary conventions, of course, but these particular conventions privilege restraint and compactness, values associated with the "real" word of the novel, as opposed to the dilation and extravagance that are offered as Joan's besetting sins and symptoms of the feminine waywardness that causes the story to "scroll and festoon" away from linearity and closure.$^{20}$ If Joan's solution to the mystery relies on Gothic precedent, it is also economical: "Then all at once I knew. It was Arthur. The whole thing was Arthur. He'd found out about the Royal Porcupine, he must've known for some time. He'd been watching me all along, not saying anything; it would be like him not to say anything. But he'd made a decision about me finally, a pronouncement, thumbs down, I was unworthy, I would have to go, and this was his plan to get rid of me" (p. 325).

The reasoning makes perfect sense given the entirety of the action so far. First of all, this behavior is completely in character for the man whose only regular activity has been represented as judging and repudiating former associates. Second, only Arthur has a credible motive for threatening Joan, in that only Arthur has in any significant respect been betrayed by her multiple identities. Third, Arthur has by far the greatest opportunity both to spy on Joan and to deliver the messages when she is least likely to expect them.

Of course, the reasoning is also consistent with the "central plot" of the Gothic, which Atwood has identified as the apprehension "my husband is trying to kill me." ${ }^{21}$ Certainly Joan, who says later that she is "hooked on plots" (p. 342), deals over and over with this apprehension as her life turns more and more Gothic. But Atwood goes on to suggest that the popularity of the Gothic may rest on reader recognition: "I think it is consumed in such great quantities by women because secretly they think their husbands are trying to

\footnotetext{
${ }^{20}$ Patricia Parker brilliantly traces the long association between the figure of the fat lady and rhetorical strategies of dilation and copiousness in "Literary Fat Ladies and the Generation of the Text," in Patricia Parker, Literary Fat Ladies: Rhetoric, Gender, Property (London: Methuen, 1987), pp. 8-35.

${ }^{21}$ Martens, "Mother-Figures," p. 49.
} 
kill them. ${ }^{\prime 22}$ The potentiality of men to be murderers as well as rescuers of dependent women is inscribed in the culture, as well as in the fictions the culture produces. The "plot" against women, and particularly against wives, is not only, and not even primarily, something that writers of Gothics create. For this reason, it is important that the Gothic elements in Lady Oracle cannot be psychologized satisfactorily, even though they mesh with Joan's own psychic proclivities. The telephone calls, the dead animals, and the threatening messages are indubitably part of the landscape that Joan shares with Arthur. They are not merely her fictions, fantasies, or hallucinations. They demand an explanation in the "real" world.

Joan stages a fake drowning and leaves Canada for the Italian village of Terremoto, "moving earth." The name has affinities with the popular romance tradition ("they wanted the earth to move"), but it also suggests ontological instability: the ground on which the apparent frame story rests may well have the propensity to shift without warning. There she constructs a Gothic analogue to her own situation, sending the bad woman/wife/sacrificial victim Felicia, the character with whom she identifies in spite of the informing values of the genre, into the maze that has functioned as structural metaphor for both the generic Gothic plot and the plot of Lady Oracle. The climactic scene at the center of this maze begins with a passage that is strikingly similar to the recognition scene in which she deduced that Arthur was the source of the anonymous threats; then it modulates into a conflation of her own situation with Felicia's.

Then she knew. Redmond was the killer. He was a killer in disguise, he wanted to murder her as he had murdered his other wives. . . . Then she would always have to stay here with them, at the center of the maze. . . . He wanted to replace her with the other one, the next one, thin and flawless ....

"Don't touch me," she said, taking a step backward. She refused to be doomed. As long as she stayed on her side of the door she would be safe. Cunningly, he began his transformations, trying to lure her into his reach. His face grew a white gauze mask, then a pair of mauve-tinted spectacles, then a red beard and moustache, which faded, giving place to burning eyes and icicle teeth. Then his cloak vanished and he stood looking at her sadly; he was wearing a turtle-neck sweater.

"Arthur?" she said. Could he ever forgive her? [p. 376-77]

${ }^{22}$ Ibid. 
The transformations undergone by the hitherto rapacious-mouthed Redmond take him through the identities of the men that have had most influence on Joan: her father, the commando and anesthetist, whom she cannot quite get over suspecting of having killed her mother; the Polish Count, Paul, who believed that women want to be raped and that in a woman physical deformity is worse than idiocy; the Royal Porcupine, Chuck Brewer, who tried first to compete with her and then to persuade her to leave Arthur for him; and the man in the ravine, who has both exposed himself to the young Joan and given her a daffodil and who has become the prototype for the enigmatic partner of the powerful, unhappy woman in the poem "Lady Oracle." In this passage, these men are evidently threatening, and their appearances here disclose the threat that has always been latent in each of them.

When Arthur emerges, however, he triggers only reflexive guilt: "Could he ever forgive her?" Of all the men in her story, he is the only one to have arisen from her Gothic imagination, in that Joan met him while she was acting out a scene she intended to write and in fact mistook him for the villain of her piece. Of all the men in her story, he is also the only one whom she has not presented as inherently dubious, as duplicitous, as a potential "killer in disguise." She is, in fact, fondly solicitous of the qualities she deems marks of his innocence or eccentricity-his lack of curiosity about the many university extension courses she claims to be taking in order to account for the time she spends writing, for instance, or his propensity to be aware of her existence only in the moments between the peaks of his ideological fervor and the troughs of his political disillusionment (p. 236). Their marriage, she has continually pointed out, is ordinary, normal, in fact better than average. And this representation of a "working" marriage is part of a commentary on the notion of marriage as a desired outcome, the terminus of the romance plot.

Joan's Gothic continues toward its climax:

Redmond resumed his opera cloak. His mouth was hard and rapacious, his eyes smoldered. "Let me take you away," he whispered. "Let me rescue you. We will dance together forever, always."

"Always," she said, almost yielding. "Forever." Once she had wanted these words, she had waited all her life for someone to say them.... She 
pictured herself whirling slowly across a ballroom floor, a strong arm around her waist. ...

"No," she said. "I know who you are."

The flesh fell away from his face, revealing the skull behind it; he stepped towards her, reaching for her throat.... [p. 377]

The dance that has been Joan's metaphor for the ideal merger of art and heterosexual love has become a dance of death, symbolic of the union that terminates the traditional Gothic and embalms its heroine forever in the romance plot. Despite its seductive twining, this plot is linear and teleological. It leads somewhere, and its climax reveals its ultimate malignancy. When the heroine has negotiated the maze and has finally reached its center to become the sanctioned object of desire, she is so reduced by having achieved coincidence with the demands of the hero and the society he represents that she is in effect inanimate, "placed" forever in an attenuated identity defined and controlled wholly by the man who bestows it. More insidiously, she is now in the position of the wife, and thus the bad woman, the victim, whom the hero must transcend in order to aspire toward fresh objects of desire, toward "the next one, thin and flawless." Always ready to identify with the wrong woman on the other side of the story, the one who violates boundaries and refuses to remain on one side, Joan had reflected earlier, "In a fairy tale I would be one of the two stupid sisters who open the forbidden door and are shocked by the murdered wives, not the third, clever one who keeps to the essentials: presence of mind, foresight, the telling of watertight lies" (p. 170). The story behind the story of romantic love is the story of Bluebeard, and she knows that in this narrative tradition for every triumphant survivor there is a roomful of corpses.

Yet at this crisis point in the novel, when Joan opens her eyes, hears footsteps, and reports, "I opened the door. I knew who it would be" (p. 377), Atwood averts the revelation that seems encoded both in Gothic precedent and in the internal logic of the plot. Despite the fact that Joan has in effect sent for Arthur and despite the evidence that Arthur is the only possible source of the threatening calls, messages, and dead animals, the man on the other side of the door is a complete stranger. Even more significant, in the final chapter where this discovery is reported, the narrative voice reverts to the chatty disorganization that is the characteristic note of the castrated 
woman: "I didn't really mean to hit him with the Cinzano bottle. I mean, I meant to hit someone, but it wasn't personal. I'd never seen him before in my life, he was a complete stranger. I guess I just got carried away: he looked like someone else ... (p. 378)." Whereas the penultimate chapter promised to reveal the mystery at the center of the labyrinth - the identity of the man trying to kill the protagonistthis final chapter returns the discourse to banality. The most extreme plot complication is never resolved. There is no further mention of the messages or the dead animals. Instead, Joan resumes responsibility for most of the events of the story: "It did make a mess; but then, I don't think I'll ever be a very tidy person" (p. 380). Her own flakiness, her psychic dispersal and lack of control, are once again presented as the key problems.

In this way, Atwood carefully betrays her implicit ending, an ending whose implications have been worked out with equal care in Joan's revision of the conclusion to her own novel, Stalked by Love. In the process, "stalked by love" is revealed to be an appropriate title as well as a typical one. Earlier Joan confided that she had been trying for years to get the words love and terror into the same title (p. 32), and in this final exploration of the Gothic structure it seems that the sanctioned conclusion, the "rescue" that wrenches the heroine away from the horrors and temptations of the maternal body and restores her to the patriarchy by subsuming her to the hero in marriage, exposes the most fundamental source of violence in the genre: in a society that defines all possible male-female relations in terms of masculine control and constraint, heterosexual love is terror for women. The intricate skein of power relations that allows the hero to "save" the heroine by claiming her as his own is far more entangling and entrapping than the feminine labyrinth.

But Atwood displays this revelation within the imbedded narrative only to withhold it from the frame narrative. As a consequence, it remains an insinuated climax that can gesture toward an unequivocal closure without in any way realizing that closure. By the logic of the plot, the point of Lady Oracle might well be that all men are killers, given the right circumstances. As Joan reflects when she is wondering whether her father murdered her mother, "Anything is the sort of thing anyone would do, given the right circumstances" (p. 200), and when "circumstances" consist of a version of reality 
that builds dominance into its fundamental structure, the privileged will inevitably be oppressors. In a subsequent novel, Bodily Harm (1982), Atwood gave this observation a much darker formulation: the reiterated answer to the question of why people in powercolonialists, whites, men-do unspeakable things to other people is "because they can get away with it," "because they can. ${ }^{123}$ In Lady Oracle, however, she is committed to exploring the assumptions behind the question. Is the masculinist version of "reality," which builds dominance into its fundamental structure, the only version of reality? The only conceivable version? The only imaginable version? Is it pervasive, seamless, universal? Does it rule out all other possibilities? Is there no place for "woman" beyond the impossibly constricted role the masculinist culture has provided for her? And if "woman" speaks, can her voice do anything more than affirm the established asymmetries, resonate as the silence in opposition to which the masculine logos emerges as present and powerful?

It is precisely the tone of Lady Oracle-its familiarity, its banality, its flakiness-that precludes such a grim resolution. In her extreme dispersal, which she represents as her characteristic "untidiness," the castrated woman forestalls any such climactic recognition, and in this gesture defers forever the narrative closure that would enclose her in the romance plot. The emphasis shifts to the character and to the character's act of storytelling and away from the threatened ending of the story. The model for the narrative thus shifts abruptly to therapy: self-revelation, or talking cure. To be sure, the desired end of such a "cure" is still the restoration of the speaker to the patriarchal order, an outcome that Jacques Lacan has termed the "repatriation of alienated signifiers. ${ }^{\text {"24 }}$ And in the concluding chapter of Lady Oracle, Atwood has Joan embracing the implications of "repatriation" with the same enthusiasm that she has brought to the recognition of her status as excessively deficient, abundantly

\footnotetext{
${ }^{23}$ Margaret Atwood, Bodily Harm (New York: Bantam, 1982), pp. 114, 280. Other formulations of the principle occur on pp. 134, 167, 170 and 240. The Handmaid's Tale (1986) is in many respects the story of how they can and what they do.

${ }^{24}$ I am indebted to Dianne Hunter's essay, "Hysteria, Psychoanalysis, and Feminism: The Case of Anna O.," in The (M)other Tongue, pp. 89-115, for cuing my own feminist rereading of this loaded phrase.
} 
deprived. Eagerly admitting all her putative former errors, Joan resolves to return to Canada, her patria, and to submit herself to the paternal law governing the economy of the Same, which she has ambiguously violated by an act of perverse mirroring: she has misrepresented her escape as her death. Furthermore, a culminating revelation makes "repatriation" such an encompassing metaphor that it dictates a radical reinterpretation of the entire preceding story. Joan has not herself been the author of her own confession. In return for immunity from prosecution, she has already turned over the ownership of her signifiers to the phallic pen of the reporter who had been on the Other Side of the door: "It was nice of him not to press charges when he came to. At first I thought it was only because he wanted the story: reporters are like that. I talked too much, of course, but I was feeling nervous. I guess it will make a pretty weird story, once he's written it; and the odd thing is that I didn't tell any lies. Well, not very many. Some of the names and a few other things, but nothing major"(p. 378).

But the emphasis on the triviality of the lies, occurring as it does in a context that affirms loquacity as one of Joan's characteristic deficiencies, suggests that on the contrary, the entire narrative has been mediated not only by the paternal authority of the male ghost writer ${ }^{25}$ but by Joan's equally characteristic tendency to fabricate identities as a bid for male approval. The seemingly regressive move whereby the entire narrative is recuperated as a masculinist production, a confession "as told to" a controlling masculine author, thus establishes the whole inflated narrative as equivocally revelatory, if indeed it reveals anything at all about Joan's purported problems. In acknowledging herself to be congenitally lacking, eternally prone to dilation and prevarication, Joan has wiggled out of the authority for her own story. Instead, she has affirmed her identity as "an artist, an escape artist," someone who resists enclosures ranging from the romance plot to the universe in which all men are potential killers: "I'd sometimes talked about love and commitment, but the real romance of my life was that between Houdini and his

\footnotetext{
${ }^{25}$ Robert Lecker introduces this phrase in his analysis of the multiple narrative voice in Lady Oracle-a voice that insinuates "every ' $\mathrm{I}$ ' is a lie" (p. 194). See his "Janus Through the Looking Glass: Atwood's First Three Novels," in The Art of Margaret Atwood, ed. Davidson and Davidson, pp. 177-203.
} 
ropes and locked trunk; entering the embrace of bondage, slithering out again. What else had I ever done?"' (p. 367).

\section{III}

In this way, Lady Oracle presents the characteristically "feminine" deficiencies of excess, uncontrollability, and unreliability as means of evading the already-inscribed plots that act as conspiracies against woman as Other-that is, in both the Irigarayan and the Gothic sense, against the Other woman. This notion of narration as a retracing of well-worn paths to a preordained and patriarchically sanctioned conclusion is dramatized in Joan's first attempt at writing the climax of Stalked by Love, where a female character enters the Gothic labyrinth. As convention dictates, this character is the self-contained and exemplary heroine Charlotte, who reaches the center of the maze to find only "an open gravelled oblong with a border of flowers, the daffodils already in bloom. Disappointingly, it was empty" (p. 366). But the initial naturalization of a formerly uncanny "center" leads her on to the naturalistic solution of the whole mystery while placing her in danger so that the hero must intervene to rescue her:

From behind her came a mocking laugh-Felicia's! "There wasn't room for both of us," she said, "One of us had to die."

Just as Charlotte was sinking into unconsciousness, Felicia was flung aside like a bundle of old clothes, and Charlotte was gazing up into the dark eyes of Redmond. "My darling," he breathed hoarsely. Strong arms lifted her, his warm lips pressed her own. [p. 366]

In this first, socially sanctioned version of the Gothic climax, Charlotte's defining neatness-she is hampered from escape by her attempt to wind up her yarn as she runs-betrays her. But if this betrayal delivers her over to her enemy, it thereby makes her available to the "strong arms" of the hero, who can now intervene to rescue her, establishing himself as loving rather than menacing and establishing her as the heroine, the female character who is guaranteed survival precisely because she has been susceptible to victimization. The malignant enemy has been revealed as both natural and female, and her motive affirms the ideology that governs the romance plot: "There wasn't room for both of us. ... One of us had 
to die." Just as the feminine, maternal maze in the traditional Gothic exists to be rendered unamazing, the Other woman exists to be exorcised as redundant, in the way, too much to be accommodated by the heterosexual couple embodying the forces of resolution and restoration in this genre.

At this point Joan expresses for the first time her dissatisfaction with her inherited plot: "That was the way it was supposed to go, that was the way it had always gone before, but somehow it no longer felt right. I'd taken a wrong turn somewhere; there was something, some fact or clue, that I had overlooked" (pp. 366-67). Her conviction that this "repatriating" resolution is inadequate to the sense of possibility generated by the preceding story suggests that "repatriation" itself is a version of the amputation principle whereby women can make gains only by making complementary sacrifices. In the Gothic, a woman gains safety and a place in society by sacrificing the power associated with the maternal body, and by the logic of the plot this sacrifice involves estranging herself from the Other woman-from the threatening possibilities of her own status as Other and from the potential power inherent in female association. Conversely, in Joan's epic poem, "Lady Oracle," the eponymous heroine is "enormously powerful, almost like a goddess," but the price she pays is as familiar a component of contemporary stories about career women as it is of fairy tales-"it was an unhappy power" (p. 248) - and the plot in which she figures inverts the Gothic formula to preclude terminal rewards: "There were the sufferings, the hero in the mask of a villain, the villain in the mask of a hero, the flights, the looming death, the sense of being imprisoned, but there was no happy ending, no true love" (p. 259).

Both these models of the heroine's text, the traditional and the inverted (and the "unhappy power" motif of the inverted version is at least as familiar, defining a dilemma that entraps characters ranging from the Lady of Shalott to Joan's own mother), present a myth of origins for the female "self" that stresses isolation and estrangement. Joan apprehends that the conclusions of such stories overlook something, leave out something important, and the various female bodies that haunt her while remaining invisible to the masculine gaze suggest that such societally sanctioned constructions of the female quest for identity are intended to limit a subversive mul- 
tiplicity that, paradoxically, inheres in the feminine Other precisely because that Other is defined in opposition to the unified, phallic self.

In other words, the threat of the feminine derives from the fact that it is defined by an act of marginalization, by a thrusting of "woman" to a position outside the order of the Same. Because she has been constructed not as self-same but as utterly different, she resists gestures of unification that belatedly attempt to control the implications of her Otherness. In Lady Oracle, a number of the female characters have more than one identity, or an identity that in some respects contradicts the received wisdom about possible combinations of power and happiness. Joan's mother tries to dismiss Aunt Lou, for instance, as "bitter and frustrated because she didn't have a huband," but Joan reflects, "To me she seemed a lot less bitter and frustrated than my mother, who, now that she'd achieved and furnished her ultimate house, was concentrating more and more of her energy on forcing me to reduce" (p. 88). Aunt Lou seems to be conducting a pleasant and stable relationship with a married man and has a job with a sanitary napkin manufacturer that significantly puts her in charge of one of the most unsanctioned aspects of female sexuality, menstruation, and makes her an authority on female maturation and reproduction, whereas Joan's mother has internalized the terms of her own constriction to become an authority only on reduction. ${ }^{26}$

Similarly, the disorientingly named Leda Sprott, the cult leader who seems to have put on a version of Olympian knowledge and power without having to suffer Olympian rape, is reincarnated as the Reverend Eunice P. Revelle and empowered to perform legal marriages despite the fact that the new identity arose from an evasion

\footnotetext{
${ }^{26}$ See my "Writing — and Reading — the Body: Female Sexuality and Recent Feminist Fiction," Feminist Studies 14 (Spring 1988), 121-42, for a more detailed examination of menstruation as a conventionally unrepresented aspect of female sexuality (along with urination, defecation, and giving birth). Joan discovers the evidence of her mother's "terrible anger" only after her mother's death, in a photograph album where all the faces of the men have been razored out. She immediately identifies the rage with the constriction of her mother's identity: "I could almost see her doing it, her long fingers working with precise fury, excising the past, which had turned into the present and betrayed her, stranding her in this house, this plastic-shrouded tomb from which there was no exit" (p. 201).
} 
of the law ("Leda Sprott owes a little money here and there," she confides to Joan [p. 231]). Loosely associated with the prepatriarchal mystery religion figure of the Great Mother, whose home was the subterranean labyrinth, ${ }^{27}$ this doubled Fat Lady has-and can discern in Joan-powers, capacities in the plural. Like Aunt Lou, she tends to utter prophecies that in the best oracular tradition are wholly ambiguous, subject to at least two contradictory interpretations. Central among these is the injunction that forms part of her eclectic wedding ceremony: "Avoid deception and falsehood; treat your lives as a diary you are writing and that you know your loved one will someday read, if not here on this side, then on the other side where all the final reconciliations will take place" (p. 227). This platitude, like the fortune cookie messsage "It is often best to be oneself" (p. 257), seems to be part of a system of adjurations supporting the popular notion of a female "self" lurking underneath the various alternative identities that must be dimissed as false. But in both cases the message is complicated by context: the recipient of the fortune cookie is not Joan but the "paragon" Marlene, and the speaker who urges that Joan "avoid deception and falsehood" is operating under an assumed name. Moreover, the notion that Joan's life is a "diary... that you know your loved one will someday read," resonates insidiously at the conclusion of the novel, when the story of Joan's life is revealed to have been "told to" a male ghost writer and to contain lies. The presumption of an eventual audience appears to dictate more, rather than less, invention.

Joan's mother stands in implicit opposition to these multiple and physically excessive female characters, and Joan represents her mother's whole life as one of self-restraint in the expectation of an eventual reward: "She used to say that nobody appreciated her, and this was not paranoia. Nobody did appreciate her, even though she'd done the right thing, she had devoted her life to us, she had made her family her career as she had been told to do, and look at us" (p. 200). In her "astral" manifestations, this mother always appears the way she looked in Joan's childhood: around thirty years old, rigorously girdled, and "colored in" with cosmetics. But it is

\footnotetext{
${ }^{27}$ Atwood discusses the myth of the Great Mother and her association with the labyrinth in the interview with Cathrine Martens. Godard works especially with this myth, and with the Demeter/Persephone myth, in "My (M)other, My Self."
} 
this manifestation that the child Joan initially perceived as misleadingly narrow, an arbitrary reduction of her mother's multiplicity, which she tried first to shield from, then to expose to, the masculine gaze:

Although her vanity tables became more grandiose as my father got richer, my mother always had a triple mirror, so she could see both sides as well as the front of her head. In the dream, as I watched, I suddenly realized that instead of three reflections she had three actual heads, which rose from her toweled shoulders on three separate necks. This didn't frighten me, as it seemed merely a confirmation of something I'd always known; but outside the door there was a man, a man who was about to open the door and come in. If he saw, if he found out the truth about my mother, something terrible would happen, not only to my mother but to me. I wanted to jump up, run to the door, and stop him, but I couldn't move and the door would swing inward....

As I grew older, this dream changed. Instead of wanting to stop the mysterious man, I would sit there wishing for him to enter. I wanted him to find out her secret, the secret that I alone knew: my mother was a monster. (p. 7o)

The dreams about her mother's hydra-headedness and the man on the "other side" of the door are structurally analogous to the Gothic recognition scenes that Joan first writes and then enacts near the close of the novel. Moreover, the mirrors that allow her mother to make herself into the requisite object of masculine desire, and thus to make herself into an exemplary mirror that will reflect back exactly what the phallocentric culture wishes to see, are transformed by the dream into portals leading to the revelation of feminine monstrosity, of woman as irreducibly multiple. In Joan's experiments with automatic writing, the triple mirrors lead into a labyrinth identified both with the unconscious and with the maternal.

As Claire Kahane has noted, the Gothic heroine negotiates the labyrinth in order to leave it behind. Her discovery of her "self" at the center of the maze allows her to transcend the maze altogether in a final repatriation that isolates her forever from the twinings of a seductive and dangerous femininity. In Lady Oracle, however, the Gothic quest is travestied in the account of a Brownie rite of passage:

You ... had to close your eyes and be turned around three times, while the pack chanted,

Twist me and turn me and show me the elf, 
I looked in the water and there saw...

Here you were supposed to open your eyes, look into the enchanted pool, which was a hand-mirror surrounded by plastic flowers and ceramic bunnies, and say "Myself." The magic word. [p. 64]

At the center of the twistings and turnings, the place of the self, is a mirror, single this time. But what does it mean that the self is identified with a mirror?

In the opening passage, Joan had bewailed her failure in these terms: "My life had a tendency to get flabby, to scroll and festoon like the frame of a baroque mirror." The reserve and self-effacement of a frame, which both supplements and sets boundaries for the thing it is framing, is here betrayed specifically as a failure of mirroring: the border that scrolls and festoons distracts from the primary business of reflection. The simile may recall Irigaray's discussion of the posited feminine as a flat mirror, simultaneously the product and the maintenance of the order of the Same, that "old dream of symmetry. ${ }^{\prime 28}$ In Lady Oracle, Joan relates her life as a series of attempts to be an exemplary mirror to the masculinist culture, reflecting back only what she is called upon to reflect. But despite what she represents as her best efforts, the enterprise is self-sabotaging.

First of all, it turns out that in order to be an ideal reflector she must sustain several completely separate identities: nurturing and bubble-headed wife, shy and middle-aged author of mass-market fantasies for women, kinkily sexy quondam mistress, and exotic and otherworldly cult "poetess." The multiple identities are necessary precisely to sustain the myth of her own accessory status-her own supplementarity and thus her own deficiency.

Second, it turns out that the mirror is the vehicle for the recognition of her own radical plurality. Looking in it to find "Myself," Joan finds instead another labyrinth, itself the distorted double of the maze in Stalked by Love, and enters it only to come out with another identity, the "dark twin" of the poem "Lady Oracle." In this novel, mirrors confirm not the unity of the self but the difference inherent in the operation of reflection, and this difference opens up

\footnotetext{
${ }^{28}$ The opening chapter of Speculum of the Other Woman, on Freud's treatment of female sexuality as the symmetrical complement of both male sexuality and male desire, is titled "The Blind Spot of an Old Dream of Symmetry" (pp. 11-129).
} 
the possibility of dis-integration, of subversive and perhaps even salvific multiplicity. Luce Irigaray has noted how the Cartesian subject of cogito ergo sum discovers-on reflection-that he is thinking, and makes of this mirror image a founding certainty. But observing how the cogito splits the self into thinker and thought-of only to suture up the split before it can be acknowledged, she asks, "What if, therefore, the crucial thing to do were rather, or especially, to conclude that the other exists?" ${ }^{29}$ Joan is continually adjured to "be yourself," but in Atwood's novel being yourself is a trick done with mirrors, a feat requiring coincidence with a reflection that is unalterably other. She must be what is seen, and only that; and if the demand implies an impossible act of self-annihilation, it is consonant with what fashion magazines, for example, urge on young women as a matter of course. And ironically, this adjuration to become solely the visible self is fully consonant with the privileging of visibility and the sole phallus in the judgment that defines the condition of femininity as one of castration: nothing to be seen.

But what if "no-thing" meant a number of things, a number of identities, for example, or even a number of irreconcilable "truths" about the relation of femininity to masculinity? After Joan has conducted her heroine, Charlotte, to the center of the maze and concluded that the conventional resolution involves "a wrong turn somewhere" (p. 366), she enters the maze again, this time in the persona of her Gothic alter ego, the wife and villainness Felicia. Stumbling into the center, Felicia comes upon a collection of her own-and Joan's-avatars: two women who look "a lot like her, with red hair and green eyes and small white teeth," one who looks like Aunt Lou and one who is clearly the Fat Lady and who wears not only the tutu and the pink tights of Joan's fantasies but, in an allusion to one of the most painful incidents of Joan's childhood (pp. 43-52), has "two antennae, like a butterfly" sprouting from her head and " $a$ pair of obviously false wings ... pinned to her back" (p. 375). Having ascertained that all these women are, as she is, Lady Redmond, Felicia arrives at the culminating revelation the labyrinth offers: "Every man has more than one wife. Sometimes all at once, sometimes one at a time, sometimes ones he doesn't even know about" (p. 376). Yet it is

\footnotetext{
${ }^{29}$ Irigaray, Speculum, p. 183 (my emphasis).
} 
precisely in their revealed multiplicity that these wives have become void for Redmond. The labyrinth that throughout the development of the plot has been associated with the threat of an entangling and potentially unresolvable femininity ("Some say as how there's no center to the maze," reports one of the novel's faithful retainers [p. 209]) has become a means of containment and ultimately of eradication. Felicia realizes that she is "trapped here with these women.... And wasn't there something peculiar about them? Wasn't their skin too white, weren't their eyes too vague?" (p. 376). Furthermore, she cannot turn back: " 'Back?' said the first woman. 'We have all tried to go back. That was our mistake." " After such knowledge, the only possible return is to the husband who can now be revealed as the man who is trying to kill her.

But the central "truth" of this imbedded story-that all men are killers who dread, and for this reason menace, female multiplicity, forcibly reducing it to no-thing-is immediately evaded, for the imbedded story is not the truth of the novel. Or not the only truth of the novel: by this time the whole convention of imbedding has become as unresolvable as the centerless maze. In fact, it is increasingly unclear, as Lady Oracle scrolls and festoons into its conclusion what, exactly, is the "real" story and what strands of plot may be subsumed as inventions, fantasies, projections, or hallucinations. Contemplating possible endings for Stalked by Love, Joan reflected earlier,

I knew what had to happen. Felicia, of course, would have to die; such was the fate of wives. Charlotte would then be free to become a wife in her turn. But first she would have to have a final battle with Redmond and hit him with something (a candelabrum, a poker, a stone, any hard sharp object would do), knocking him out and inducing brain fever with hallucinations, during which his features and desires would be purified by suffering and he would murmur her name. She would nurse him with cold compresses and realize how deeply she loved him; then he would awaken in his right mind and propose. [p. 348]

The last chapter of Lady Oracle, when Joan confesses to having knocked out the man on the other side of the door with a Cinzano bottle and adds, "There's something about a man in a bandage" (p. 
379), flirts with this conclusion, as with the conventional conclusion of the genre "nurse novels" written by Paul, the Polish Count. But here the man in a bandage is an altogether new stand-in for the hero, a development that makes purification through suffering beside the point. The conventions are so haphazardly applied, in fact, that this ending might belong to a completely different novel-or it might be the beginning of a completely different novel. Narrative multiplicity has not resolved unambiguously into unity. Instead of a recognition, a final moment of self-coincidence, Joan seems once again to disperse, this time into plans for more stories, presumably involving more authorial personae, and into her throwaway disclosures about the reporter's mediation and her own lies. Indeed, the lengthy "rising action" of the classical plot has been betrayed by the lack of a climax - or by the fact that the climax is at the very least difficult to locate, recurring, diffuse; as if the model of plot construction here were something more polymorphous and perverse.

In this calculated miming of "the feminine" as a condition of essential deficiency, Atwood has in effect created an alternative narrative structure, a structure that in important ways is not modeled on masculine sexuality (as is the "classic" linear and teleological plot, with its situation, rising action, climax, and denouement) and that resists the masculinist ideologies encoded in the "classic" structure by refusing to make a univocal revelation the point of the whole story, in this way refusing to privilege a single version of "the truth" as definitive. Like female desire in this novel, the central questions are developed only to resist containment and unitary embodiment, and as a consequence they remain disconcertingly present, bobbing like gloriously inflated Fat Ladies above any ostensible resolution.

IV

Lady Oracle emerges from this discussion as a prime example of representation with a difference, a novel in which the Other Woman makes herself known through ruptures and dislocations of the economy of the Same. Yet difference can always be read as no-thingand indeed was read this way when Lady Oracle first came out. The following quotations are from two major reviews: 
It may be that the genre [of "popular feminist-oriented fiction"] is not congenial to Atwood's real gifts: perhaps the very confusion of "Lady

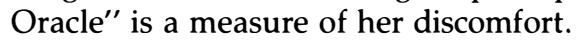

The novel does not develop, it meanders, circling around and turning on itself-letting its contours be defined by the chaos of the heroine's psyche. $^{30}$

In the first quotation, the feminine deficiency is ascribed directly to the writer: Lady Oracle is "confused," because Atwood is "confused" (although the reviewer tries to mitigate the criticism by making an unfortunate choice of genre the source of Atwood's "discomfort"). In the second quotation, the feminine deficiency is ascribed, more flatteringly, to the writer's creation, and Atwood is credited with having invented (presumably for some ethical or therapeutic purpose) a woman whose psyche is in "chaos"- that is, a woman whose essence is deficiency or lack. In either case, both the self and the narrative are presumed to be aspiring toward a familiar model of coherence, and dis-unity is read as somebody's failing: predictably, as the failing of some woman.

It is not surprising that Lady Oracle can be read back into the discourse of the Same-can be read as an attempt to emulate a patriarchally constructed order, an attempt that in various ways and for various reasons fails to live up to the masculinist standard and so emerges as merely disordered: characterized by "confusion," "chaos," a structure that "does not develop, it meanders." Each of the chapters in this book has begun from a survey of existing criticism on the writer under discussion. In each case, the main tendencies of the criticism suggest that readings reinscribing feminist writing in the order of the Same are historically the easiest and the most accessible readings, even when they misconstrue or falsify elements of the fiction they purport to explain. In each case, even the dominant feminist readings work against the acknowledgement of conscious innovation and experimentation on the part of feminist writers. In many respects, it appears that the novice reader's question, "What is she trying to say?" has been granted unique relevance to feminist narrative. Of course, "trying to say" is an untenable

\footnotetext{
${ }^{30}$ Katha Pollitt, New York Times Book Review, 26 September 1976, 7-8; LeAnne Schreiber, Time, 11 October 1976, 98.
} 
formulation, implying as it does not only a "trying" that falls short of complete success (thus the reader must "say" what the author was incapable of articulating) but also a theory of writing as an unproblematic "saying" subsequently cloaked in language (thus the reader's job is to disentangle meaning from the duplicitous veils of rhetoric in which it is swathed).

The question remains whether such reductive readings are inevitable-whether when difference speaks, it can be heard, and if it can be heard, how one might learn to listen for it. In a passage from her essay "This Sex Which Is Not One," Irigaray writes, "One would have to listen with another ear, as if hearing an 'other meaning' always in the process of weaving itself, of embracing itself with words, but also of getting rid of words in order not to become fixed, congealed in them. ${ }^{1{ }^{31}}$ In the context of contemporary feminist narrative, I find this notoriously difficult description both lucid and revelatory. "Listening with another ear" suggests attunement to a project involving representation with a difference, representation that generates an elusive "other meaning" by questioning, subverting, and parodying masculine models in the process of mimicking them. Such a project is inherently political and, furthermore, implies that politics is not divorced from issues of language. The political cannot be understood as an unmediated "saying," a communication of a "content" separable from "form."

Contemporary feminist narrative is both experimental and political inasmuch as it is characterized by pervasive parodies, mimicries, and subversions. My enterprise has been to suggest that if one listens with an ear not entirely attuned to the discourse of the Same, if one acknowledges that when difference speaks, its productions will deviate from-while still relying on-sanctioned modes of discourse, then the Other Side and the Other Woman become manifest as a ballooning of possibilities.

${ }^{31}$ Luce Irigaray, "This Sex Which Is Not One," in This Sex Which Is Not One, trans. Catherine Porter (Ithaca: Cornell University Press, 1985), p. 29. 
